Gordana Petković Muzej grada Novog Sada Novi Sad, Srbija gordana.petkovich@gmail.com
DOI: https://doi.org/10.18485/slovenika.2017.3.1.4

UDK: 94(=163.6)(439)"1939/1945" 94(=163.41:=163.6)(497.1)"1939/1945"

Pregledni rad

\title{
Akcija spasavanja dece srpske i slovenačke nacionalnosti iz logora Šarvar u Drugom svetskom ratu
}

Sažetak

Ovaj rad se bavi akcijom spasavanja zatočenika, a pre svega dece iz mađarskog logora Šarvar u Drugom svetskom ratu, koju je predvodio dr Irinej Ćirić, episkop bački. Akcija je obuhvatala ukupno 2.800 dece, od kojih je njih 206 bilo slovenačke nacionalnosti, 180 majki sa odojčadima i oko 647 staraca. Da bi se prikazao značaj celokupne akcije, opisan je i rad Dečje bolnice u Novom Sadu, kao i drugi vidovi pomoći logorašima od strane srpskih pravoslavnih crkvenih opština Eparhije bačke. Rad je zasnovan na dokumentima koji se čuvaju u arhivi Srpske pravoslavne crkvene opštine novosadske i u Muzeju Vojvodine. Na taj način se nastoji predstaviti jedan poseban, ali nedovoljno proučavani vid saradnje srpskog i slovenačkog naroda u periodu Drugog svetskog rata.

Ključne reči: Drugi svetski rat, logor Šarvar, Irinej Ćirić, akcija spasavanja dece, Novi Sad

Izvestan broj radova u srpskoj / jugoslovenskoj istoriografiji bavio se stradanjem srpskog stanovništva, uglavnom iz Bačke, $u$ mađarskim logorima tokom Drugog svetskog rata. ${ }^{1}$ Malo je poznato da su u tim logorima, među logorašima, bili i internirani Slovenci.

Drugi svetski rat, koji je zahvatio i Kraljevinu Jugoslaviju, u aprilu 1941. godine doveo je do njenog raspada i podele jugoslovenske

${ }^{1}$ Ova tema je obrađena u sledećim radovima: Zvonimir Golubović, Šarvarska golgota 1941-1945, Novi Sad 1995; Zločini okupatora u Vojvodini, knj. 1, Novi Sad 1945; Vladimir Rotbart, Jugosloveni u mađarskim zatvorima i logorima 1941-1945, Novi Sad 1988; Danilo Urošević, Srbi u logorima Mađarske, Novi Sad 1995, 1. izdanje i 2. izdanje 2016. 
teritorije među članicama fašističke koalicije - Nemačkom, Italijom, Mađarskom i Bugarskom, dok je u Zagrebu 10. aprila proglašena Nezavisna država Hrvatska. ${ }^{2}$ Mađarska vojska okupirala je Bačku, Baranju, Međumurje i Prekomurje, i odmah je počela da primenjuje represivne mere, od kojih je jedna bila i interniranje stanovništva u logore. Internacijom su bili obuhvaćeni Srbi koji su se naselili u Bačkoj i Baranji po završetku Prvog svetskog rata, kao i Slovenci naseljeni u Prekomurju, izbegli sa teritorije koja je po Rapalskom ugovoru (1920) pripala Italiji. ${ }^{3}$

Među mađarskim logorima najozloglašeniji je bio radni logor Šarvar. ${ }^{4}$ To je bio najveći mađarski logor i, prema nekim podacima, $u$ njega je tokom Drugog svetskog rata bilo internirano između 8.500 i 9.500 zatočenika. U Šarvaru je bilo zatočeno i oko 600 Slovenaca, koji su poticali iz mesta Pince-Marof, Benica, Petišovci, Kamovci i Dolga vas (Ravnik 2010, 226).

Logor Šarvar je dobio naziv prema gradiću koji se nalazio zapadno od Budimpešte, na magistralnom železničkom pravcu Budimpešta-Sombathelj. Početkom 20. veka Šarvar je bio industrijsko mesto, sa šećeranom i fabrikom svile. Međutim, posle Prvog svetskog rata fabrika svile je promenila vlasnika i ubrzo je ugašena. Upravo se $u$ ovoj bivšoj svilari tokom Drugog svetskog rata nalazio sabirni logor za izbegle Poljake, ${ }^{5}$ a zatim logor za internirane Jugoslovene

2 Nezavisna država Hrvatska obuhvatala je područje nekadašnje Banovine Hrvatske i Vrbaske banovine, odnosno, područje koje danas zauzima Republika Hrvatska, osim Istre, Rijeke, Zadra i ostrvâ Krk, Cres, Lošinj, Lastovo i Vis.

${ }^{3}$ Jože Vidič (o kome će više reči biti u nastavku teksta) u vezi s tim kaže: „To so bile izbeglice sa teritorija »Soškog fronta $1915 / 17$ «koji se niso želeli vratiti na porušene domove na teritoriju koja je po rapalskom ugovoru pripala Italiji ili koji su kasnije iz ekonomskih razloga ili zbog fašističkog terora napustili svoje domove i prešli u Jugoslaviju."

${ }^{4}$ Logori sličnog karaktera su u Mađarskoj osnovani u više mesta (Barč, Nađkanjiža itd.) (Rotbart 1988).

${ }^{5}$ Na početku Drugog svetskog rata, posle vojničkog sloma Poljske (1939), veliki broj poljskih vojnika prebegao je u Mađarsku, u želji da izbegne nemačko zarobljeništvo. Oni su smešteni u sabirne logore, a jedan od njih nalazio se u Šarvaru, u zgradi bivše svilare (Rotbart 1988, 44-45). 
(Rotbart 1988, 44-45). Kada su juna 1941. godine stigli prvi internirani kolonisti iz Bačke, u logoru je bilo svega nekoliko Poljaka. ${ }^{6}$

Zvanično ime logora bilo je Mađarski kraljevski logor za interniranje - Šarvar. Sastojao se od devet fabričkih hala u kojima su bili smešteni internirci, zgrade uprave logora, zgrade za stražare i jedna baraka koja je služila kao kuhinja. Uslovi su bili loši - fabričke hale od betonskih zidova, malo svetlosti, neudobni, minimalni drveni ležajevi, veliki broj logoraša u jednoj hali (Golubović 1995, 125-136). Zbog ovakvih okolnosti, kojima se mogu pridodati loša ishrana i nehigijenski uslovi, veliki broj logoraša je oboleo i umro. Smatra se da je tokom rata u Šarvaru i drugim okolnim logorima umrlo oko 1.200 logoraša, među kojima je bio i veliki broj dece (Rotbart 1988, 45). ${ }^{7}$ Najviše logoraša umrlo je u zimu 1941/42. godine. Glad, hladnoća i bolesti najviše su pogodili decu i majke sa bebama (Rotbart 1988, 45).

Značajnu ulogu u pokretanju i sprovođenju akcije spasavanja zatočenika iz logora Šarvar imala je Srpska pravoslavna crkva i Eparhija bačka, na čelu sa episkopom dr Irinejem Ćirićem. ${ }^{8}$ Srpska pravoslavna crkva je tokom Drugog svetskog rata pretrpela velike ljudske i materijalne gubitke. Njene eparhije nalazile su se u različitim okupacionim režimima, tako da su se pod mađarskom vlašću našle dve eparhije - Budimska i Bačka. Mađarske okupacione vlasti priznale su Srpsku pravoslavnu crkvu, ali su njenu imovinu, i eparhijsku i manastirsku, stavile pod sekvestar. Istovremeno, pokušavali su da

\footnotetext{
${ }^{6}$ Među Poljacima su bila trojica lekara - dr Armejski, dr Boževski i dr Volf, koji su u logoru ostali još neko vreme i pružali medicinsku pomoć logorašima (Rotbart 1988, 45).

${ }^{7} \mathrm{U}$ posebnom delu šarvarskog groblja sahranjeno je oko 750 osoba (Rotbart 1988, 45).

${ }^{8}$ Irinej (Ivan) Ćirić (Sremski Karlovci, 1884. - Novi Sad, 1955), episkop bački. Rođen je u uglednoj karlovačkoj porodici, od oca Isidora i majke Eveline. Školovao se u mestu rođenja, Novom Sadu, Moskvi i Beču, gde je doktorirao (1908). Zamonašio se iste godine u manastiru Hopovo. Za episkopa timočkog izabran je 1919, a zatim je premešten u Eparhiju bačku (1922), kojom je upravljao 33 godine. Bio je angažovan u radu više međunarodnih crkvenih pokreta, u kojima je predstavljao Srpsku pravoslavnu crkvu. Bavio se slikanjem, poezijom, prevođenjem i crkvenim pojanjem. Tokom Drugog svetskog rata izabran je za člana Gornjeg doma mađarskog parlamenta, ali nije prisustvovao zasedanjima. Posle rata, 17 meseci je proveo u kućnom pritvoru (Petković 2015, 7-61).
} 
obrazuju autokefalnu Mađarsku pravoslavnu crkvu, ali su pokušaji ostali bezuspešni zahvaljujući otporu koji su pružili episkop bački Irinej Ćirić i episkop budimski Georgije Zubković. ${ }^{9}$

U Novom Sadu je, ubrzo po započetoj akciji interniranja kolonista iz Bačke, formiran Odbor u okviru Srpske pravoslavne crkvene opštine, koji je iskoristio ideju favorizovanja crkve od strane okupatora, poslavši svoje predstavnike vlastima i istakavši da bi humanitarna akcija trebalo da se obavi preko crkve, na osnovu čega je dobijeno odobrenje da se internircima može dostaviti pomoć u vidu hrane, odeće, obuće i lekova. ${ }^{10}$ Prva akcija dostavljanja pomoći obavljena je u junu 1941. godine, u vreme dok su se internirci nalazili u logoru na novosadskom aerodromu. Sa ovakvom praksom je nastavljeno, tako da je pomoć nadalje odnošena u logor Šarvar. Među logorašima, najugroženija su bila deca i majke sa bebama, te je njima pomoć bila dragocena, ali je bilo još značajnije izbaviti ih iz logora. Napravljen je plan da se deca izvode iz logora, uz saglasnost mađarskih okupacionih vlasti, i da se razmeštaju u porodicama širom Eparhije bačke. ${ }^{11}$

Najveći doprinos ovoj akciji, posle episkopa Irineja Ćirića, dali su Jovan Ćulum, predsednik, i Kosta Hadži, sekretar novosadske Crkvene opštine. Oni su često odlazili u logor Šarvar radi dostavljanja pomoći, ili u Budimpeštu radi obavljanja poslova, koji su bili u vezi sa interniranim osobama, u Ministarstvu unutrašnjih dela. O tome svedoče sačuvani računi o izdacima prilikom njihovih putovanja - troškovi puta, smeštaja, troškovi za slatkiše kupljene za decu, troškovi večere za lekare Poljake, kao i večere za službenike logora, zatim novac doktorima u logoru za preglede, fotografisanje grupa u logoru, prilog Opštini Šarvar za tamošnju sirotinju. ${ }^{12}$ Jedan do-

\footnotetext{
${ }^{9}$ Arhiv Eparhije bačke. Izveštaj o radu pravoslavnoga episkopa Eparhije bačke za vreme okupacije u ratu 1941-1944. godine. (br. 581 od 25 (12) oktobra 1949. u Novom Sadu).

${ }^{10}$ Muzej Vojvodine. Intervju sa Kostom Hadžijem (inv. br. 26. 012).

${ }^{11}$ Muzej Vojvodine. Intervju sa Kostom Hadžijem (inv. br. 26. 012).

${ }^{12}$ Prilikom boravka u Šarvaru u aprilu 1942, Jovan Ćulum je dao prilog od 300 penga Opštini Šarvar za tamošnju sirotinju. Priznanica o tom prilogu čuvana je u kasi novosadske Crkvene opštine „kao poseban dokument za dnevnu upotrebu kod vlasti“. Arhiv Crkvene opštine Novi Sad (u daljem tekstu: Arhiv CO Novi Sad), Šarvar - obračun izdataka, 15. april 1942.
} 


\section{G. Petković}

Akcija spasavanja dece srpske i...

kument je posebno važan jer nam pruža podatak o tome da je prvi transport dece iz logora u Šarvaru krenuo ka Novom Sadu, u pratnji Jovana Ćuluma, početkom aprila 1942. godine. ${ }^{13}$ Čim je Ministarstvo unutrašnjih dela dozvolilo da se iz logora izvedu muška deca do 14 i ženska deca do 15 godina starosti, i razmeste po porodicama srpske nacionalnosti u Bačkoj, odmah je za Novi Sad, početkom aprila, krenulo 186 dece. Iz Šarvara je u Bačku stiglo ukupno 16 transporta, sa 2.812 dece, 188 odojčadi i 184 porodilje (Rotbart 1988, 51). Najviše dece smešteno je u Novom Sadu (710), Somboru (598), Srbobranu (112), Subotici (110), Bačkoj Palanci (106), Molu (102), Staparu (95), Zmajevu (95) i Senti (74), ali ih je bilo i u mnogim drugim mestima u Bačkoj.

Akcija spasavanja dece iz Šarvara obuhvatila je i slovenačku decu. Episkop Irinej je smatrao da njih treba primiti i razmestiti po porodicama. ${ }^{14}$ Prema dostupnim podacima, srpske porodice $\mathrm{u}$ Bačkoj primile su 206 slovenačke dece. Prema Rotbartu, u mestima u kojima su bila smeštena slovenačka deca, pravoslavni sveštenici su najčešće vodili računa da ona redovno pohađaju rimokatoličku versku nastavu i da poštuju i praktikuju obrede predviđene rimokatoličkim dogmama (Rotbart 1988, 51-52).

Jože Vidič, rođen u slovenačkom selu Kamovci, preživeo je rat upravo zahvaljujući ovoj akciji spasavanja koju su sproveli episkop bački dr Irinej Ćirić i crkvene opštine Eparhije bačke. U logor Šarvar je dospeo kao dete od šest godina. Iz rodnog sela je, preko Lendave, sa porodicom krenuo za Šarvar 23. juna 1942. godine, zajedno sa 588 stanovnika drugih sela. Vožnja do logora je trajala više od 24 sata, a ljudi su prevoženi stočnim vagonima. Prema sećanju J. Vidiča, kada je omogućeno da deca mlađa od 15 godina mogu izaći iz logora, majka mu je, želeći da ga ubedi da ode, doslovno rekla: „Ako ostaneš u logoru, umret ćeš kad dođe zima“. Jože je pristao na odlazak u nepoznato. Na put je krenuo sa kartončićem obešenim o uzicu oko vrata, na kojem je pisalo „Ó Szivac (Stari Sivac) “. ${ }^{15}$ Putovanje od Budimpešte preko Subotice i Vrbasa do Sivca trajalo je oko 42 sata. Po pristizanju u Sivac primio ih je paroh, i tu su deca dobila hranu,

13 Put u Šarvar po prvi transport dece trajao je od 31. marta do 6. aprila 1942. Arhiv CO Novi Sad. Putni troškovnik, 8. april 1942.

14 Arhiv CO Novi Sad. Pismo „Joci“ (Jovanu Ćulumu, prim. aut.) od nepoznatog pošiljaoca (najverovatnije od Koste Hadžija, prim. aut.), Novi Sad, 2. jul 1942.

15 Prema sećanju J. Vidiča. 
prvi put od polaska na put. Jože je smešten u kuću porodice Mirosavljev, kod udovice Marije, koja je imala petnaestogodišnjeg sina Vladu. U kući Mirosavljevih je pomagao oko vinograda i kućnih poslova. Posle gotovo dve godine, Jože je premešten u drugu porodicu, gde je boravila i njegova sestra Pavla. U Starom Sivcu je Jože stekao prijatelje srpske, nemačke i mađarske nacionalnosti. Tu je naučio da piše, čak i ćirilicu, a učio ga je prijatelj Duško Živanov, sa kojim je o Božiću i Uskrsu odlazio u pravoslavnu crkvu. Jože Vidič se vratio u Sloveniju u avgustu 1945. godine. Njegova sećanja su i danas vrlo živa, a česte posete Šarvaru i Sivcu, sve do današnjih dana, govore o tome koliki je trag na njemu ostavio ovaj period. Jože Vidič smatra da je episkop bački Irinej Ćirić, po broju ljudi spasenih iz logora, zaslužniji od Oskara Šindlera, ali da ta činjenica nije u dovoljnoj meri poznata. ${ }^{16}$

Zahvaljujući inicijativi i podršci episkopa Irineja, tokom ratnih godina je u Novom Sadu radila Bolnica srpskih pravoslavnih crkvenih opština Eparhije bačke. Može se slobodno reći da je to bila druga faza akcije spasavanja dece iz logora. Bolnica je osnovana isključivo sa jednim ciljem - da leči decu iz logora Šarvar i drugih mađarskih logora koja su bila obolela od tuberkuloze. Funkcionisala je zahvaljujući prvenstveno redovnim prilozima crkvenih opština Eparhije bačke, zatim dobrovoljnim prilozima vernika, ali je dobijala i značajnu novčanu pomoć od Kraljevske ugarske vlade. ${ }^{17}$ Po dobijanju dozvole od strane mađarskih vlasti, episkop Irinej je, na predlog novosadske i subotičke crkvene opštine, doneo odluku „da se svim crkvenim opštinama odobrava zajedničko otvaranje i izdržavanje jedne ovakve bolnice“, a da će doprinos crkvenih opština i zadužbina njenom finansiranju odrediti Eparhijski upravni odbor. ${ }^{18}$ Iako je dozvola za otvaranje stigla, bolnica u Novom Sadu nije odmah mogla početi sa radom, jer nisu bili obezbeđeni svi tehnički uslovi.

16 Detaljnije o iskustvu J. Vidiča videti u: Mojca Ravnik, „Sprejeli so nas za svoje“. Otroci internirancev iz taborišča Sárvár na madžarskem v reji pri kmetih v Bački med 2. svetovno vojno, Traditiones, 39/1, 2010, 225 - 238.

${ }^{17}$ Prema podacima, ukupan prihod Bolnice iznosio je 550.000 penga, od kojih su 300.000 dale crkvene opštine Eparhije bačke, 196.000 mađarska vlada, 44.000 je bilo od priloga pojedinaca, 10.000 od eparhijskog poljoprivrednog dobra u Sirigu, a 3.000 penga iz drugih izvora (Hadži 1944, 170-174).

${ }^{18}$ Arhiv CO Novi Sad. Dopis upućen CO Mol (br. D. 68/1942, od 5. juna 1942). 


\section{G. Petković}

Akcija spasavanja dece srpske i...

Poteškoće su bile brojne, ali je najvažnije bilo obezbediti adekvatan prostor. Potreba za otvaranjem bolnice, u kojoj bi se lečili internirci iz mađarskih logora, bila je velika. I mađarskim vlastima je bilo $\mathrm{u}$ interesu da se oslobode bolesnih logoraša.

Episkop Irinej je sazvao konferenciju za 24. jul 1942. godine, kojoj su prisustvovali predstavnici senćanske, srbobranske, subotičke i novosadske crkvene opštine, kao i predstavnici nekadašnjih udruženja - Kola srpskih sestara, Hrišćanske zajednice i Srpske ženske zadruge. Na ovoj konferenciji je dogovoreno sve što je bilo važno za funkcionisanje bolnice - od materijalnih troškova, preko pitanja osoblja i upravljanja, do objekata u kojima će biti smeštena deca (Sava, episkop šumadijski 1992).

Pravilnik o upravi i rukovođenju Bolnicom srpskih pravoslavnih crkvenih opština Bačke eparhije predviđao je da na lečenje mogu biti primana deca iz logora koju su pregledali lekari Srpske pravoslavne crkvene opštine, pa i ona deca koja su puštena na slobodu, uz nalaz lekara i odobrenje bolničke uprave. ${ }^{19}$ Svi bolesnici su imali besplatnu negu i lečenje, dok bolničko osoblje nije smelo primiti nijednu nagradu ili poklon od bolesnika ili rođaka. Bolnicom je upravljao Bolnički odbor, koji se sastojao od 15 članova iz redova crkvenih opština i ženskih udruženja, a imenovao ga je Eparhijski upravni odbor Eparhije bačke, sa episkopom Irinejem na čelu. Bolnički odbor je, zapravo, upravljao svim poslovima bolnice - vršio je nadzor nad svim njenim službenicima, brinuo o prikupljanju materijalnih sredstava za izdržavanje Bolnice, postavljao i otpuštao bolničko osoblje, određivao plate i u svakom pogledu brinuo o tome da Bolnica udovolji svim svojim zadacima. Takođe, Bolnički odbor je svakog meseca podnosio izveštaje o radu Bolnice Eparhijskom upravnom odboru, a episkopu Irineju je dostavljao prepise zapisnika sa svojih sednica. ${ }^{20}$ Izvršni organi ovog Odbora bili su njegov predsednik i sekretar. Pravilnik je predviđao i Nadzorni odbor, sastavljen od pet članova iz redova crkvenih opština, koji je kontrolisao materijalno poslovanje, sve račune i inventare. Upravnik Bolnice je bio iz redova stručnog osoblja - lekar koji je vršio „celokupnu stručnu upravu“i nadzor nad

\footnotetext{
${ }^{19}$ Arhiv CO Novi Sad. Pravilnik o upravi i rukovođenju Bolnicom srpskih pravoslavnih crkvenih opština Bačke eparhije (UO br. 946/1942, od 17. avgusta 1942).

${ }^{20}$ Arhiv CO Novi Sad. Obaveštenje episkopu Irineju o dostavljanju prepisa zapisnika sednice Bolničkog odbora, održane dan ranije (br. D. 194/1943, od 17. februara 1943).
} 
bolničkim osobljem. Svako odeljenje, a bilo ih je tri, imalo je svog šefa, zaduženog za nadzor nad stručnim osobljem u svom odeljenju, za red, disciplinu i higijenu. ${ }^{21}$

Već sredinom avgusta 1942. godine ustanovljeno je Uputstvo svim odeljenjima i ambulanti o postupku u vezi sa brojnim stanjem. Uputstvo je sadržalo stroga pravila oko prijema i otpusta pacijenata, postupanja sa dokumentacijom, kao i za svakodnevno utvrđivanje brojnog stanja pacijenata. Uputstvo su, u ime novosadske Crkvene opštine, potpisali njen predsednik Jovan Ćulum i sekretar Kosta Hadži. ${ }^{22}$

Mnogo truda i materijalnih sredstava trebalo je obezbediti da Bolnica započne sa radom. Prilozi u novcu i drugim potrepštinama koje su davali pojedinci i crkvene opštine bili su brojni, mađarske okupacione vlasti su ustupile deo opreme, ali je i pored toga nedostajalo određenih sredstava. Različiti pokušaji i načini crkvenih opština i pojedinaca, uz pomoć kojih su se nabavljala neophodna sredstva za Bolnicu, zabeleženi su u dokumentima sačuvanim u arhivi novosadske Crkvene opštine.

Episkop bački Irinej obišao je, već 2. avgusta 1942. godine, sva tri bolnička odeljenja, interesujući se za zdravstveno stanje dece i za prilike u bolnici. Episkopa i njegovu pratnju dočekali su upravnik dr Jovan Popović i svi lekari (Nova pošta, br. 170, 4. avgust 1942). Za prvog upravnika Bolnice postavljen je dr Jovan Popović, ${ }^{23}$ šef Prvog odeljenja (Ženskog) bio je dr Đorđe Ognjanović, ${ }^{24}$ čuveni novosadski fiziolog, dok je Drugo odeljenje (Muško) vodio dr Milutin Simić, ${ }^{25}$ Treće (Dečje) - dr Stojan Kaluđerski, ${ }^{26}$ pedijatar. Pored ovih lekara, koji su ujedno bili i šefovi odeljenja, u dokumentima se nalaze

\footnotetext{
${ }^{21}$ Arhiv CO Novi Sad. Pravilnik o upravi i rukovođenju Bolnicom srpskih pravoslavnih opština Eparhije bačke (UO br. 946/1942. od 17. avgusta 1942).

${ }^{22}$ Arhiv CO Novi Sad. Uputstvo svim odeljenjima i ambulanti o postupku oko brojnog stanja (D. 97/942, od 14. avgusta 1942).

${ }^{23}$ Popović dr Jovan (Bačko Gradište, 1881. - Beograd, 1972), lekar socijalne medicine.

${ }^{24}$ Ognjanović dr Đorđe (Sremski Karlovci, 1898. Novi Sad, 1957), lekar-internista, primarijus.

${ }^{25}$ Simić dr Milutin (Lovra kod Budimpešte, 1895. Novi Sad, 1976), lekar-infektolog, primarijus.

${ }^{26}$ Kaluđerski dr Stojan (Stari Vrbas, 1905. - Novi Sad, 1976), lekar-pedijatar, primarijus.
} 


\section{G. Petković}

Akcija spasavanja dece srpske i...

i imena drugih lekara koji su bili angažovani: dr Anđa Jovanović, dr Ksenija Kalenić Drašković, kao i studentkinje medicine - Dragica Selaković, Ljubica Gubaš Turčan, Dušanka Šilić i Mira Živojinović Radojčić. U ovoj akciji su svesrdnu pomoć Dečjoj bolnici pružili dr Branko Ilić, ${ }^{27}$ dr Branko Kešanski, dr Jovan Nenadović, dr Radivoj Kalenić i dr Vladimir Jakovljević iz Novog Sada, kao i drugi lekari. ${ }^{28}$

Često se dešavalo da na molbe građana, koji su u svojim porodicama imali decu iz logora i za njih molili prijem u Bolnicu, odgovor bolničke uprave bude negativan zbog popunjenosti kapaciteta. Međutim, dok još i nije bilo problema te vrste, početkom juna 1942. godine, Uži odbor novosadske crkvene opštine organizovao je terensku službu, koja je bila dužna da obilazi bolesnu decu iz Šarvara smeštenu u Novom Sadu. ${ }^{29}$

Prema kućnom redu Bolnice, bolesnici su „bili dužni da se strogo pridržavaju lekarskih propisa i dnevnog reda: vremena ustajanja, ležanja, šetnje, kupanja, zanimanja“. Radi sprečavanja širenja zaraze moralo se strogo voditi računa o higijeni (o čistoći u sobama, upotrebi pribora za ličnu higijenu, upotrebi toaleta), dok su posete malim bolesnicima bile moguće samo uz dozvolu lekara i u tačno određeno vreme. Prema kućnom redu, a iz zdravstvenih, vaspitnih i psiholoških razloga, svako dete je - u zavisnosti od stanja bolesti, uzrasta i interesovanja - imalo obavezu da se bavi nekim korisnim zanimanjem ili razonodom. Školska deca su se tako bavila, uz pomoć lokalnih učitelja, čitanjem, pisanjem, računanjem i veronaukom. ${ }^{30}$ Decu je gotovo svakog dana obilazio glumac Milan Ajvaz. On je vreme sa bolesnom decom provodio u razgovoru, a jednom prilikom je priredio i predstavu „Knez Ivo od Semberije“, u kojoj su devojke sa Ženskog odeljenja „igrale... za interni svet“..31

${ }^{27}$ Ilić dr Branko (Žabalj, 1889. - Novi Sad, 1966), lekar-ginekolog, gradonačelnik Novog Sada i kolekcionar.

${ }^{28}$ Imena lekara navedena su na osnovu sačuvanih dokumenata $\mathrm{u}$ fondu Arhiva crkvene opštine novosadske, koja svedoče o radu Dečje bolnice.

${ }^{29}$ Početkom juna 1942. u Novom Sadu je bilo smešteno između 20 i 30 dece, koja su prethodno bila u logoru. Arhiv CO Novi Sad (D. 73/942, od 6. juna 1942).

${ }^{30}$ Arhiv CO Novi Sad. Kućni red Bolnice srpskih pravoslavnih crkvenih opština Eparhije bačke (D. 155/942)

${ }^{31}$ Arhiv CO Novi Sad. Izveštaj sekretara Bolničkog odbora o radu Bolnice u mesecu martu 1943. 
Dnevnik ishrane je vođen svakog dana, a sadržao je broj lica koja su dobijala obroke (pacijente i osoblje), kompletan jelovnik za pet obroka, potpis ekonoma, kao i potpise predsednika novosadske Crkvene opštine Jovana Ćuluma i sekretara Koste Hadžija - u znak potvrde da su jelovnik videli. ${ }^{32}$ Pored Dnevnika ishrane vođena je i Knjiga obračuna utrošene hrane, i to za svaki dan pojedinačno, sa podacima o broju lica koja su se hranila (ponekad ih je bilo i preko 160 dnevno), sa detaljnim spiskom svih upotrebljenih namirnica i njihovim količinama. Ovi spiskovi su, takođe, potpisivani od strane istih lica. Na spiskovima namirnica, pored povrća, mesa i voća, ponekad su se našli i bombone i keks.

Do kraja rata je kroz bolnicu prošao 441 bolesnik, od kojih je njih 40 umrlo (Zločini okupatora... 1945, knj. 1, 244). Po završetku rata je bolnica prestala sa radom.

Eparhija bačka sa episkopom i uz pomoć svojih crkvenih opština nastojala je da spase što veći broj interniranih, prvenstveno dece, iz šarvarskog logora. Veliki broj dece je izbavljen iz logora i lečen $u$ Dečjoj bolnici, a zatim razmeštan po porodicama. Međutim, bilo je još mnogo odraslih koje je trebalo izbaviti. Radi realizacije ovog važnog posla sačinjen je poziv (raspis), od strane Užeg odbora Srpske pravoslavne crkvene opštine novosadske, namenjen crkvenim opštinama. U njemu su se nalazila uputstva o načinu na koji se vršilo izbavljivanje. Uži odbor je obaveštavao crkvene opštine o postojanju posebnog spiska, sa oko 420 lica, na kojem su se nalazili muškarci od preko 60 godina, njihove žene, žene koje su bile same (bez obzira na godine), kao i muškarci nesposobni za rad (bez obzira na godine). Spisak je bio umnožen i poslat velikim crkvenim opštinama u Suboticu, Sombor, Sentu, Palanku, Kulu i Srbobran, a one su bile dužne da ga dostave na uvid građanima. Postupak je bio sledeći: lice koje je želelo da smesti u svoju porodicu nekoga sa spiska dostavljalo je tu informaciju svojoj crkvenoj opštini, a ona je zatim sve podatke dostavljala novosadskoj Crkvenoj opštini. Zvanična molba sa izjavom, potpisanom od strane domaćina, upućivana je Ministarstvu unutrašnjih dela. ${ }^{33} \mathrm{Na}$ ovaj način je iz logora izbavljeno i smešteno u porodice više od 600 starijih lica (Rotbart 1988).

\footnotetext{
${ }^{32}$ U Arhivu CO Novi Sad sačuvano je više ovakvih dnevnika ishrane.

${ }^{33}$ Arhiv CO Novi Sad. Raspis Užeg odbora CO Novi Sad crkvenim opštinama, 1943. (nije datiran i nema broja).
} 


\section{G. Petković}

Akcija spasavanja dece srpske i...

Logorašima su pomagali brojni pojedinci, koji su slali pakete sa hranom, odećom i obućom. Sredinom 1942. godine, novosadska Crkvena opština poslala je u logor veliku količinu pomoći - 8 vagona slame, 4 vagona kiselog kupusa, 2 vagona pasulja i druge hrane, što je doprinelo značajnom poboljšanju ishrane (Rotbart 1988, 52). Episkop bački Irinej nije propustio da se zahvali pravoslavnim vernicima na pomoći koju su pružali unesrećenim sunarodnicima.

Velika zasluga za pokretanje i sprovođenje akcije spasavanja iz logora Šarvar pripada dr Irineju Ćiriću, episkopu bačkom. Zahvaljujući njegovoj inicijativi, okupile su se brojne crkvene opštine i pojedinci, koje su zajedničkim delovanjem sprovele humanitarnu akciju spasavanja dece i ostalih iz zatočeništva. Krajem decembra 2015. godine, u Novom Sadu je postavljena izložba o ovom uglednom i zaslužnom arhijereju Srpske pravoslavne crkve. ${ }^{34}$ Izložbu je posetio izvestan broj bivših logoraša i starijih Novosađana koji su upamtili dane stradanja u Drugom svetskom ratu. ${ }^{35} \mathrm{U}$ okviru izložbe organizovan je susret nekolicine preživelih logoraša. Susretu su prisustvovali Dragica Čamdžić iz Sremske Kamenice, Jovan Dejanović, nekadašnji gradonačelnik Novog Sada, Nikola Kolar iz Kovilja, Jože Vidič iz Lendave i dr Kosta Hadži stariji, sin negdašnjeg sekretara Srpske pravoslavne crkvene opštine novosadske, pominjanog Koste Hadžija. Susret je bio veoma dirljiv i potresan - ne samo za bivše logoraše nego i za posetioce ovog programa. ${ }^{36}$ Nekadašnji zatočenici govorili su o svojim iskustvima u logoru, iako su njihova sećanja fragmentarna jer su tada svi bili deca, kao i o boravku u porodicama u koje su dospeli iz logora i u njima proveli vreme rata.

\footnotetext{
${ }^{34}$ Izložba Irinej Ćirić, episkop bački (1884-1955) održana je od 8. do 21. decembra 2015. u Kulturnom centru Novog Sada. Autorka izložbe i kataloga je mr Gordana Petković, viši kustos, istoričar Muzeja grada Novog Sada.

${ }^{35}$ Konstatacija je izneta na osnovu ličnih zapažanja autorke izložbe.

${ }^{36}$ Jože Vidič je spremno podelio svoja sećanja sa autorkom izložbe i kataloga, za priliku otvaranja izložbe doputovao je iz Slovenije u Novi Sad i bio je aktivan učesnik u pratećem programu posvećenom nekadašnjim logorašima, na čemu mu se još jednom zahvaljujemo.
} 


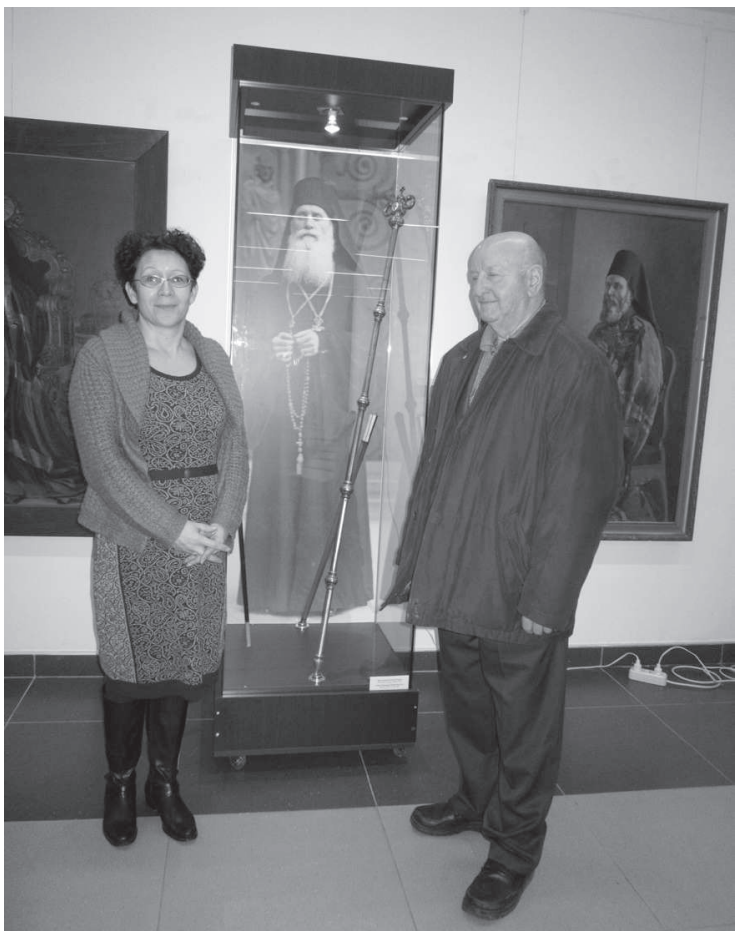

Gordana Petković i Jože Vidič na izložbi Irinej Ćirić, episkop bački (1884-1955)

Izvori - neobjavljeni

Arhiv Eparhije bačke, Fond pravoslavnog episkopa bačkog.

Arhiv Srpske pravoslavne opštine novosadske, Fond Dečje bolnice.

Muzej Vojvodine, Zbirka arhivskih dokumenata.

Izvori - objavljeni

Zločini okupatora u Vojvodini 1941 - 1944, knj. 1 1945. Novi Sad : Predsedništvo Narodne skupštine Autonomne pokrajine Vojvodine.

Literatura

Golubović, Zvonimir. 1995. Šarvarska golgota 1941-1945. Novi Sad : Matica srpska.

Hadži, Kosta. 1944. „Crkvene opštine na delu Hristove ljubavi“. Kalendar Srpske pravoslavne eparhije bačke za prestupnu godinu 1944. Ujvidek : Uprava Eparhije bačke.

Irinej, episkop bački. 1941. Arhijerejska poslanica o Božiću 1941(1942). Novi Sad : Uprava Eparhije bačke. 
Nova pošta. 1942. Nova pošta br. 170, 4. avgust.

Petković, Gordana. 2015. Irinej Ćirić, episkop bački (1884-1955). Novi Sad : Muzej grada Novog Sada.

Ravnik, Mojca. 2010. „Sprejeli so nas za svoje“. Otroci internirancev iz taborišča Sárvár na madžarskem v reji pri kmetih v Bački med 2. svetovno vojno. Traditiones 39/1 : 225-238.

Rotbart, Vladislav. 1988. Jugosloveni u mađarskim zatvorima i logorima 19411945. Novi Sad : Dnevnik - Institut za istoriju Vojvodine.

Sava, episkop moravički. 1964. „Dr Irinej Ćirić, episkop novosadsko-bački“, Bogoslovlje, sv. 1 i 2.

Sava, episkop šumadijski. 1992. Spasavanje i zbrinjavanje srpske dece tokom Drugog svetskog rata. Beograd : Kalendar Srpske pravoslavne patrijaršije. Crkva 1992.

Urošević, Danilo. 2016. Srbi u logorima Mađarske : u Barču i Šarvaru 19411945. 2. izdanje. Novi Sad : Arhiv Vojvodine; Budimpešta : Srpska samouprava u Budimpešti - Srpsko udruženje „Zora“.

Gordana Petković

Muzej mesta Novi Sad

Novi Sad, Srbija

gordana.petkovich@gmail.com

\section{AKCIJA REŠEVANJA OTROK SRBSKE IN SLOVENSKE NARODNOSTI IZ TABORIŠČA SÁRVÁR MED DRUGO SVETOVNO VOJNO}

Članek je posvečen akciji reševanja ujetnikov, predvsem otrok, iz madžarskega taborišča Sárvár, ki jo je med drugo svetovno vojno vodil dr. Irinej Ćirić, bački episkop. Akcija je skupno zajela 2.800 otrok, med katerimi je bilo 206 otrok slovenske narodnosti, 180 mater z dojenčki in približno 647 starcev. Da bi prikazala pomen celotne akcije, avtorica opiše tudi delovanje Otroške bolnišnice v Novem Sadu in druge vrste pomoči, ki so jo taboriščnikom nudile srbske pravoslavne cerkvene občine Bačke eparhije. Članek temelji na dokumentih, ki jih hranijo v arhivu Srbske pravoslavne cerkvene občine v Novem Sadu in v Muzeju Vojvodine. Na ta način avtorica poskuša predstaviti posebno, vendar nezadostno proučeno obliko sodelovanja srbskega in slovenskega naroda $\mathrm{v}$ obdobju druge svetovne vojne.

Ključne besede: druga svetovna vojna, taborišče Sárvár, Irinej Ćirić, akcija reševanja otrok, Novi Sad 
Gordana Petković

Sity Museum of Novi Sad

Novi Sad, Serbia

gordana.petkovich@gmail.com

\section{ACTION TO SAVE SERBIAN AND SLOVENIAN CHILDREN FROM THE SÁRVÁR CAMP IN WORLD WAR II}

The paper deals with the action of rescuing detainees, primarily children, from the Hungarian camp Sárvár in World War II. The action was led by Dr Irinej Ćirić, the Orthodox Bishop of Bačka. A total of 2,800 children were saved in the action and 206 of them belonged to the Slovenian ethnic group. They were accompanied by 180 mothers with infants and about 647 elderly people. In order to highlight the significance of the action, the paper also describes the work of the Children's Hospital in Novi Sad, as well as other forms of support provided by Serbian Orthodox communities of the Eparchy of Bačka. The paper is based on documents from the archives of the Serbian Orthodox Community of Novi Sad and the Museum of Vojvodina. It seeks to present a distinct, though insufficiently studied form of collaboration between Serbs and Slovenians during World War II.

Keywords: World War II, Sárvár Camp, Irinej Ćirić, action to save children, Novi Sad 